Int. Agrophys., 2019, 33, 303-311

INTERNATIONAL

\title{
Assessment of nitrous oxide emissions from agricultural soils at a local level in Poland
}

\author{
Pawet Wiśniewski* (D) \\ Department of Physical Geography and Environmental Management, University of Gdańsk, \\ Bażyńskiego 4, 80-309 Gdańsk, Poland
}

Received August 22, 2018; accepted February 25, 2019

\begin{abstract}
Nitrous oxide $\left(\mathrm{N}_{2} \mathrm{O}\right)$ is a very potent greenhouse gas whose concentration in the atmosphere is steadily increasing. Almost $80 \%$ of the annual $\mathrm{N}_{2} \mathrm{O}$ emissions in Poland originate from agriculture, and its main source is the use of agricultural soils. This study attempts to estimate the $\mathrm{N}_{2} \mathrm{O}$ emissions from agricultural soils and presents statistical analyses and spatial distributions for all Polish communes. For this purpose, a solution has been proposed which could be successfully applied by local government in order to assess $\mathrm{N}_{2} \mathrm{O}$ emissions, as well as to monitor the impact of actions undertaken to limit them. The annual $\mathrm{N}_{2} \mathrm{O}$ emissions from agricultural soils in Polish communes varies from $0.002 \mathrm{Mg} \mathrm{N}_{2} \mathrm{O}-\mathrm{N}$ to $437.77 \mathrm{Mg} \mathrm{N} \mathrm{N}_{2} \mathrm{O}-\mathrm{N}$ (with an average value of $21.13 \mathrm{Mg} \mathrm{N}_{2} \mathrm{O}-\mathrm{N}$ and a standard deviation of $23.86 \mathrm{Mg}$ $\mathrm{N}_{2} \mathrm{O}-\mathrm{N}$ ), and the cultivation of organic soils is its main source. The use of fertilizers and nitrogen fertilization with plant residues, as well as indirect emissions from nitrogen leaching, are also significant. The results may be used to provide a database for local governments, which will serve, not only to identify local emission sources related to agricultural soils, but also to properly plan and prioritize measures for its reduction.

Keywords: nitrous oxide, emission, agricultural soils, communes, Poland
\end{abstract}

\section{INTRODUCTION}

Nitrous oxide $\left(\mathrm{N}_{2} \mathrm{O}\right)$ is a greenhouse gas $(\mathrm{GHG})$ with approximately 300 times the potential to produce a greenhouse effect than carbon dioxide $\left(\mathrm{CO}_{2}\right)$ it also has an extensive duration of persistence in the atmosphere, estimated to be over 100 years (Bange, 2008; IPCC, 2013; Prather et al., 2015; Schlesinger and Bernhardt, 2013; Turbiak et al., 2011). Moreover, it is currently the number one ozone depleting gas emitted by human activities (Broucek, 2018; Portmann et al., 2012; Wilson et al., 2013). The concentration of this gas in the atmosphere has increased

\footnotetext{
*Corresponding author e-mail: p.wisniewski@ug.edu.pl
}

considerably over the past few decades (Finlayson-Pitts and Pitts, 2000; Stalenga and Kawalec, 2008; Włodarczyk et al., 2002). According to the National Centre for Emissions Management (KOBiZE, 2018), in 2016, the nitrous oxide emissions in Poland (excluding category 4 - Land Use, Land Use Change and Forestry sector) were estimated at $65,540 \mathrm{Mg}$ (4.9\% of total GHG emissions), $77.6 \%$ of which came from agriculture. Poland holds fourth place (after France, Germany and the UK) in terms of $\mathrm{N}_{2} \mathrm{O}$ emissions from the agricultural sector among the EU countries (Eurostat, 2017). Agricultural soils are mainly responsible for the share of $\mathrm{N}_{2} \mathrm{O}$ emissions from this sector being so significant - they account for $67.2 \%$ of the national $\mathrm{N}_{2} \mathrm{O}$ emissions (KOBiZE, 2018). Nitrous oxide is produced in the soil mainly as a result of nitrification and denitrification processes, as well as the process of nitrogen binding by bacteria. Many factors influence the quantity of $\mathrm{N}_{2} \mathrm{O}$ emitted from soils, e.g. climate, soil texture, temperature and soil moisture, secondary binding of nitrogen oxides in the soil, land use and cultivation, the type and amount of fertilizer doses, and biomass burnt on the ground (Bremner 1997; Hénault et al., 2012; Khalil et al., 2004; Mercik et al., 1995; Sapek, 2008).

Agricultural $\mathrm{N}_{2} \mathrm{O}$ emissions are currently being measured by direct emission measurement from a given source, and emission modelling from various sources on a global or regional scale (Bouwman, 1996; Butterbach-Bahl et al., 2013; Jarosz et al., 2013; Nyćkowiak et al., 2012; Sapek, 2008). Based on IPPC methodology (IPCC 2006), $\mathrm{N}_{2} \mathrm{O}$ emissions may be estimated using a Tier 1, Tier 2 or Tier 3 approach. Tier 1 methods are designed to be the simplest to use. Country-specific activity data are needed, but for

(C) 2019 Institute of Agrophysics, Polish Academy of Sciences 
Tier 1 there are often globally available sources of activity data estimates. Tier 2 may be applied using the same methodological approach as Tier 1 but the applied emission and stock change factors are based on country-specific or region-specific data, for the most important land-use or livestock categories. For Tier 3, higher order methods are used, including models and inventory measurement systems tailored to address national circumstances, repeated over time, and driven by high-resolution activity data which is disaggregated at the subnational level. These higher order methods provide estimates of greater certainty than the lower tiers. Although the IPPC recommends the application of the highest level methods, which will precisely respond to local changes in use or behaviour, there are as yet no reports showing the research findings concerning $\mathrm{N}_{2} \mathrm{O}$ emissions from agriculture at local levels (Wiśniewski and Kistowski, 2017a, 2017b, 2017c). However, it is clear that agriculture has the potential to play a crucial role in decreasing $\mathrm{N}_{2} \mathrm{O}$ emissions, and that it could be one of the main sectors responsible for increasing the share of renewable energy sources in the production of energy (Czubaszek and Wysocka-Czubaszek, 2018). Therefore, it is important to quantify the local $\mathrm{N}_{2} \mathrm{O}$ emissions from agricultural land. Modelling nitrous oxide emissions from soil is very complex (Nyćkowiak et al., 2013, 2014). Syp and Faber (2016) have emphasized the problems with the correct estimation of simulated $\mathrm{N}_{2} \mathrm{O}$ emissions from soils and the distinct differences that arise in its estimation depending on the methodology used.

This study attempts to estimate direct $\mathrm{N}_{2} \mathrm{O}$ emissions (from the use of mineral and organic fertilizers, cultivation of legumes, post-harvest plant residues, organic soils, and from animal excreta on pasture and grooming areas) and indirect $\mathrm{N}_{2} \mathrm{O}$ emissions (from the deposition of atmospheric nitrogen, and from nitrogen leaching) from agricultural soils for all Polish communes (according to Local Administrative Units - LAU level 2). It follows a pilot study of 48 selected communes, the results of which were presented in the author's earlier work (Wiśniewski and Kistowski, 2017c). The assessment of $\mathrm{N}_{2} \mathrm{O}$ emissions at a local level for the whole of Poland has not yet been carried out. The results may provide a database for local governments, which will allow, not only for the identification of local emission sources related to the use of agricultural soils, but also to properly plan and prioritize measures for its reduction. To date, such studies have not been conducted in Poland on a large scale.

\section{MATERIAL AND METHODS}

Poland is characterized by a high proportion of agricultural land in the total surface area (approx. $170000 \mathrm{~km}^{2}$, $54 \%$ of the country's area). A high concentration of agricultural land is observed in areas with fertile soils and in the less industrialized central and eastern parts of the coun- try. Arable land makes up the largest share in the structure of agricultural land (more than 75\%). The zonal soils of Poland cover approximately $74 \%$ of the total area, with the domination of Cambisols and Podzols. The mid-zonal soils, which include alluvial soils, half-bog soils and black earth, Calcaric Leptosols, Gleyic Phaeozems and Gleyic Podzols, cover about $25 \%$ of the territory of Poland. The out-of-zone soils are represented in Poland mainly by the Chernozems, having developed on loess. The typological diversification of soils also contributes to differences in nitrogen content (Letey and Vaughan, 2013; Ohshiro et al., 2016; Wang et al., 2016). Fotyma et al. (2004) indicate that the average content of mineral nitrogen in Polish soils is $76-90 \mathrm{~kg} \mathrm{~N} \mathrm{ha}^{-1}$ in the spring and $83-97 \mathrm{~kg} \mathrm{~N} \mathrm{ha}^{-1}$ in the autumn, including the average content of nitrate nitrogen $\left(\mathrm{N}-\mathrm{NO}_{3}\right)$ which is, 50-60 $\mathrm{kg} \mathrm{N} \mathrm{ha}^{-1}$ in the spring and $60-70 \mathrm{~kg} \mathrm{ha}^{-1}$ in the autumn.

In order to calculate $\mathrm{N}_{2} \mathrm{O}$ emissions, a method was chosen, which can be successfully applied by local government units. This method has been described earlier and implemented by Wiśniewski and Kistowski (2017c), who presented a pilot study to assess the $\mathrm{N}_{2} \mathrm{O}$ emissions from agricultural soils for 48 selected Polish communes. The suggested solution could be successfully applied by using almost exclusively the data available in public statistics. This means that the data could be accessed by local government units in order to self-assess the $\mathrm{N}_{2} \mathrm{O}$ emissions and to monitor the impact of the measures taken to reduce emissions from agricultural soils. The proposed solution is in line with the methodology and standard indicators of the IPCC $(2000,2006)$. The methods and data presented focus on Tier 1 inventories, however, in order to obtain more accurate emissions data, the method takes into account the elements of national methodology and emission factors developed by KOBiZE for the purposes of preparing annual inventory reports.

Data concerning the annual usage of mineral fertilizers, livestock and organic soil were obtained from the Local Data Bank of the Central Statistical Office (LDB CSO). The annual harvest of the main crops was determined using data regarding the area planted in individual communes and the average yield of these plants in the voivodeship (NUTS level 2), based on the National Agricultural Census 2010. Compared to the pilot study (Wiśniewski and Kistowski, $2017 \mathrm{c}$ ), the indicators used in the estimation of $\mathrm{N}_{2} \mathrm{O}$ emissions from the use of agricultural soils were reviewed and updated. Thus, the latest indicators were applied, as specified in Poland's National Inventory Report (KOBiZE, 2017) as well as default indicators recommended by the IPCC (2006).

In order to estimate the emissions related to the use of mineral fertilizers, the default nitrous oxide emission factor was used at a level of $0.01 \mathrm{~kg} \mathrm{~N}_{2} \mathrm{O}-\mathrm{N} \mathrm{kg} \mathrm{N} \mathrm{N}^{-1}$ (IPCC, 2006). This indicator was also used to estimate the mass of nitrogen entering the soil as a result of biological binding by Fabaceae plants, and plant residues. Direct emissions from 


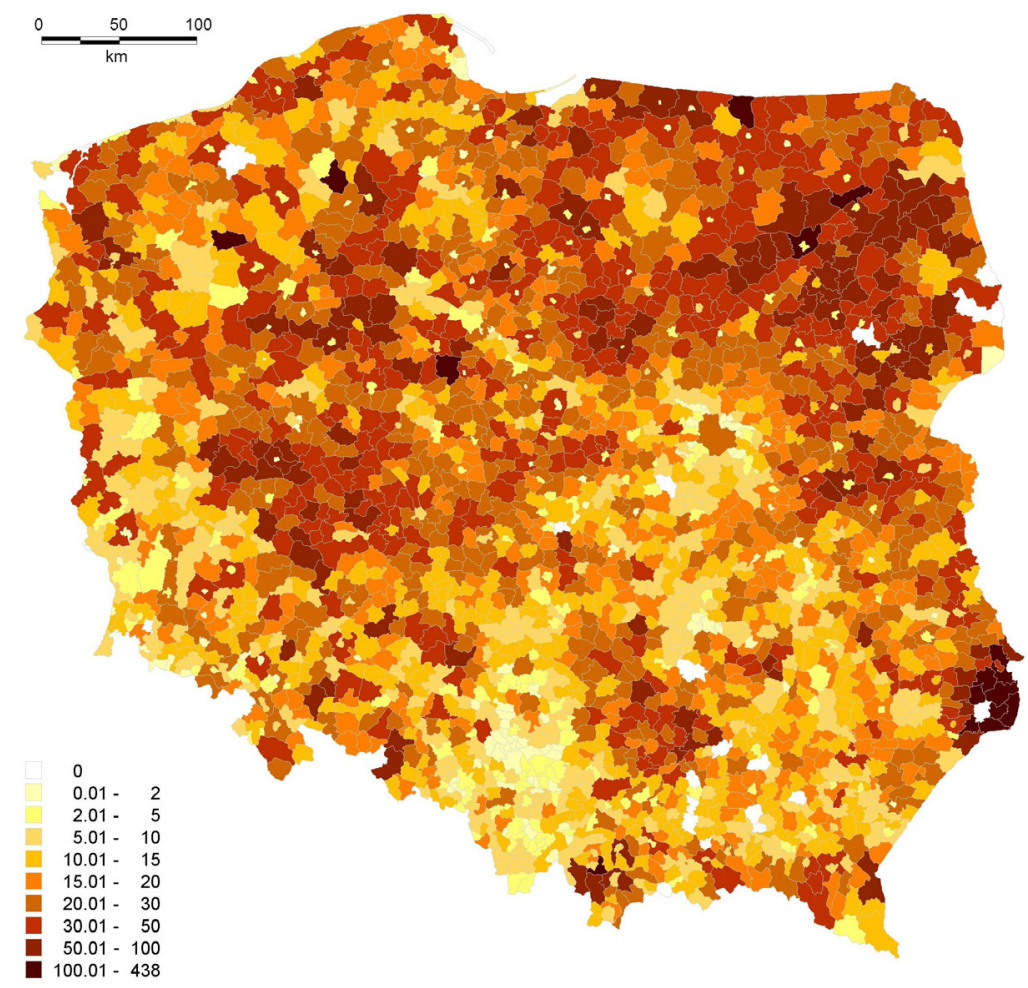

Fig. 1. Annual $\mathrm{N}_{2} \mathrm{O}$ emissions from agricultural soils in Polish communes $\left(\mathrm{Mg} \mathrm{N}_{2} \mathrm{O}-\mathrm{N}\right)$.

organic soils were estimated based on their surface area and a default emission coefficient for the cold climate, which amounts to $8 \mathrm{~kg} \mathrm{~N}_{2} \mathrm{O}-\mathrm{N}$ year ${ }^{-1}$ (IPCC, 2000). The amount of emissions from animal excreta deposited on pasture and grooming areas was estimated, however, taking into account the share of particular livestock husbandry systems in Poland as well as the default indicators of the nitrogen content in livestock manure.

Based on the results obtained, the spatial distribution of $\mathrm{N}_{2} \mathrm{O}$ emissions from agricultural soils (expressed as $\mathrm{N}_{2} \mathrm{O}-\mathrm{N}$ ) across the country was presented using GIS (MapInfo Pro software) tools. This has helped to identify and assess the spatial variability of the main anthropogenic sources of emissions associated with the use of agricultural soils, which, in the future, should facilitate the planning and prioritization of abatement measures.

\section{RESULTS AND DISCUSSION}

The calculations show that the annual nitrous oxide emissions from agricultural soils in Polish communes (excluding the communes of Łęknica, Jastarnia and Dziwnów, for which there are no data in the public statistics necessary to calculate it) range from $0.002 \mathrm{Mg} \mathrm{N}_{2} \mathrm{O}-\mathrm{N}$ in the urban-rural commune of Międzyzdroje (in the West Pomeranian Voivodeship) to $437.77 \mathrm{Mg} \mathrm{N}_{2} \mathrm{O}-\mathrm{N}$ in the rural commune of Mircze (in the Lublin Voivodeship), with an average value of $21.13 \mathrm{Mg} \mathrm{N}_{2} \mathrm{O}-\mathrm{N}$ and a standard deviation of $23.86 \mathrm{Mg} \mathrm{N}_{2} \mathrm{O}-\mathrm{N}$ (Fig. 1, Table 1). $68 \%$ of nitrous oxide emissions from agricultural soils originates from rural communes, $29 \%$ from urban-rural communes and $3 \%$ from urban communes. However, the highest average annual $\mathrm{N}_{2} \mathrm{O}$ emission from agriculture is observed in urbanrural communes. This amounts to $25.38 \mathrm{Mg} \mathrm{N}_{2} \mathrm{O}-\mathrm{N}$ and is almost $14 \%$ higher than the average emission in rural communes and over five times higher than in urban communes (Table 1).

However, it should be taken into account that estimates of agricultural emissions are highly uncertain. In a study of 48 selected Polish communes (Wiśniewski and Kistowski, 2018), the uncertainty of emission value for the agricultural sector was determined to be at a level $\pm 38 \%$, and the highest value of uncertainty in the agricultural sector occurred for $\mathrm{N}_{2} \mathrm{O}$ as a result of the high level of uncertainty in the emission factors for direct soil emissions. Wójcik-Gront and Gront (2014) estimated the level of uncertainty concerning agricultural emissions in Poland in 2011 using an alternative Monte Carlo analysis and compared it to the simplified method based on error propagation, currently used in Poland in the reports submitted under the UN Framework Convention on Climate Change and its Kyoto Protocol. For nitrous oxide emissions, the simulation results against the error propagation method showed the clear differences between these methods with an asymmetric uncertainty range of $-50.0 \%$ to $+79.9 \%$. As the emission factors for the Tier 1 method are not based on country-specific data, they may not accurately represent the agricultural characteristics of a particular country, and may be highly uncertain as a result. As emphasized by Syp et al. (2016), comparing 
Table 1. Statistical analyses of annual $\mathrm{N}_{2} \mathrm{O}$ emissions from agricultural soils according to emission sources and types of communes

\begin{tabular}{|c|c|c|c|c|c|c|c|c|}
\hline \multirow{2}{*}{ Emission sources } & \multicolumn{8}{|c|}{$\mathrm{Mg} \mathrm{N}_{2} \mathrm{O}-\mathrm{N}$} \\
\hline & Min & Max & Avg & $\sigma$ & Min & Max & Avg & $\sigma$ \\
\hline & \multicolumn{4}{|c|}{ Rural communes } & \multicolumn{4}{|c|}{ Urban-rural communes } \\
\hline Mineral fertilizers & 0 & 37.17 & 3.85 & 3.40 & 0 & 43.47 & 5.12 & 4.62 \\
\hline Natural fertilizers & 0 & 185.40 & 3.02 & 5.59 & 0 & 27.00 & 3.40 & 3.91 \\
\hline Edible pulses & 0 & 1.53 & 0.01 & 2.07 & 0 & 0.73 & 0.01 & 0.05 \\
\hline Plant residues & 0 & 404.14 & 3.43 & 18.78 & 0 & 193.86 & 3.15 & 12.42 \\
\hline Organic soils & 0.19 & 192.24 & 9.13 & 9.24 & 0 & 249.31 & 10.45 & 13.02 \\
\hline Livestock excreta & 0 & 3.19 & 0.36 & 0.40 & 0 & 2.32 & 0.37 & 0.39 \\
\hline $\begin{array}{l}\text { Deposition of } \\
\text { atmospheric } \mathrm{N}\end{array}$ & 0 & 50.71 & 1.24 & 1.67 & 0 & 7.88 & 1.48 & 1.37 \\
\hline Nitrogen leaching & 0 & 57.61 & 1.88 & 2.13 & 0 & 12.09 & 2.30 & 2.00 \\
\hline \multirow[t]{2}{*}{ Total } & 0.19 & 437.77 & 22.62 & 24.98 & 0 & 331.73 & 25.94 & 23.24 \\
\hline & \multicolumn{4}{|c|}{ Municipalities } & \multicolumn{4}{|c|}{ All communes } \\
\hline Mineral fertilizers & 0 & 7.97 & 0.64 & 0.96 & 0 & 43.47 & 3.75 & 3.77 \\
\hline Natural fertilizers & 0 & 5.73 & 0.43 & 0.68 & 0 & 185.40 & 2.78 & 4.94 \\
\hline Edible pulses & 0 & 0.17 & 0 & 0.01 & 0 & 1.53 & 0.01 & 0.06 \\
\hline Plant residues & 0 & 44.76 & 0.71 & 2.98 & 0 & 404.14 & 2.93 & 16.23 \\
\hline Organic soils & 0 & 29.75 & 2.84 & 3.37 & 0 & 249.31 & 8.60 & 10.06 \\
\hline Livestock excreta & 0 & 0.31 & 0.03 & 0.04 & 0 & 3.19 & 0.32 & 0.39 \\
\hline $\begin{array}{l}\text { Deposition of } \\
\text { atmospheric } \mathrm{N}\end{array}$ & 0 & 2.00 & 0.19 & 0.26 & 0 & 50.71 & 1.17 & 1.54 \\
\hline Nitrogen leaching & 0 & 3.08 & 0.29 & 0.40 & 0 & 57.61 & 1.78 & 2.05 \\
\hline Total & 0.04 & 49.56 & 4.99 & 5.87 & 0 & 437.77 & 21.13 & 23.86 \\
\hline
\end{tabular}

four tools for the calculation of $\mathrm{N}_{2} \mathrm{O}$ emissions under the renewable energy directive, the IPCC Tier 1 method, currently used by many countries, ignores factors which are essential in defining current emissions. The measurements performed over the course of the studies by these authors confirmed that $\mathrm{N}_{2} \mathrm{O}$ emissions depend on local climatic conditions combined with the microbiological and physical properties of the soil. Therefore, the first step in collecting data by local governments should be to investigate existing national and local statistics, industry sources, research studies and FAO statistics. The uncertainty associated with emissions will vary widely depending on the source. Therefore, further research in this field is necessary. Syp and Faber (2017) emphasize that at the present time there is a need for more detailed methods to describe the spatial and temporal patterns of ecosystem GHG exchange. In order for countries to calculate $\mathrm{N}_{2} \mathrm{O}$ emissions at the regional level, they propose using the Tier 2 - Lesschen emission factors (Lesschen-EF). The advantage of this approach is the simplicity of obtaining the necessary data. Additionally, the Tier 2 method offers mitigation measures comparable to the Tier 3 - denitrification-decomposition (DNDC) model, related to crop type, weather conditions, and management practices.

The highest $\mathrm{N}_{2} \mathrm{O}$ emissions related to agricultural land use are mainly characteristic of communes located in the northern and north-eastern part of the country (Fig. 1).
This is in line with the territorial analysis (at the level of voivodeships) of agricultural GHG emissions in Poland, carried out by Wójcik-Gront (2015). The high $\mathrm{N}_{2} \mathrm{O}$ emissions in this part of the country are related to, among other factors, the significant share of organic soils. These results confirm the assumptions of Turbiak et al. (2011), who indicated that among the various soil types, organic soils may be one of the main sources of nitrous oxide emissions. They emphasized that following the use of organic soils for agricultural purposes, which involves lowering groundwater levels, there is an intensive organic matter mineralization in these soils. According to Okruszko and Piaścik (1990), in the climatic conditions of Poland, about $10 \mathrm{Mg} \mathrm{ha}^{-1}$ of organic matter is subjected to annual mineralization, which results in the release of up to $400 \mathrm{~kg} \mathrm{ha}^{-1}$ of mineral nitrogen into the environment. Włodarczyk et al. (2002) emphasize that the organic soil showed about 4 times as much denitrification activity (as measured by $\mathrm{N}_{2} \mathrm{O}$ emission and $\mathrm{NO}_{3}{ }^{-}$depletion) and on average 27 times as much dehydrogenase activity as the mineral soil. In terms of the quantity of $\mathrm{N}_{2} \mathrm{O}$ emissions from land use, compared to the rest of the country, the communes in south-eastern Poland (in the vicinity of Hrubieszów in the Lublin Voivodeship) are particularly unusual (Fig. 1), the largest area of agriculturally used Chernozems in Poland, is located there. In addition, in this area, lands of the former State Agricultural Farm are 

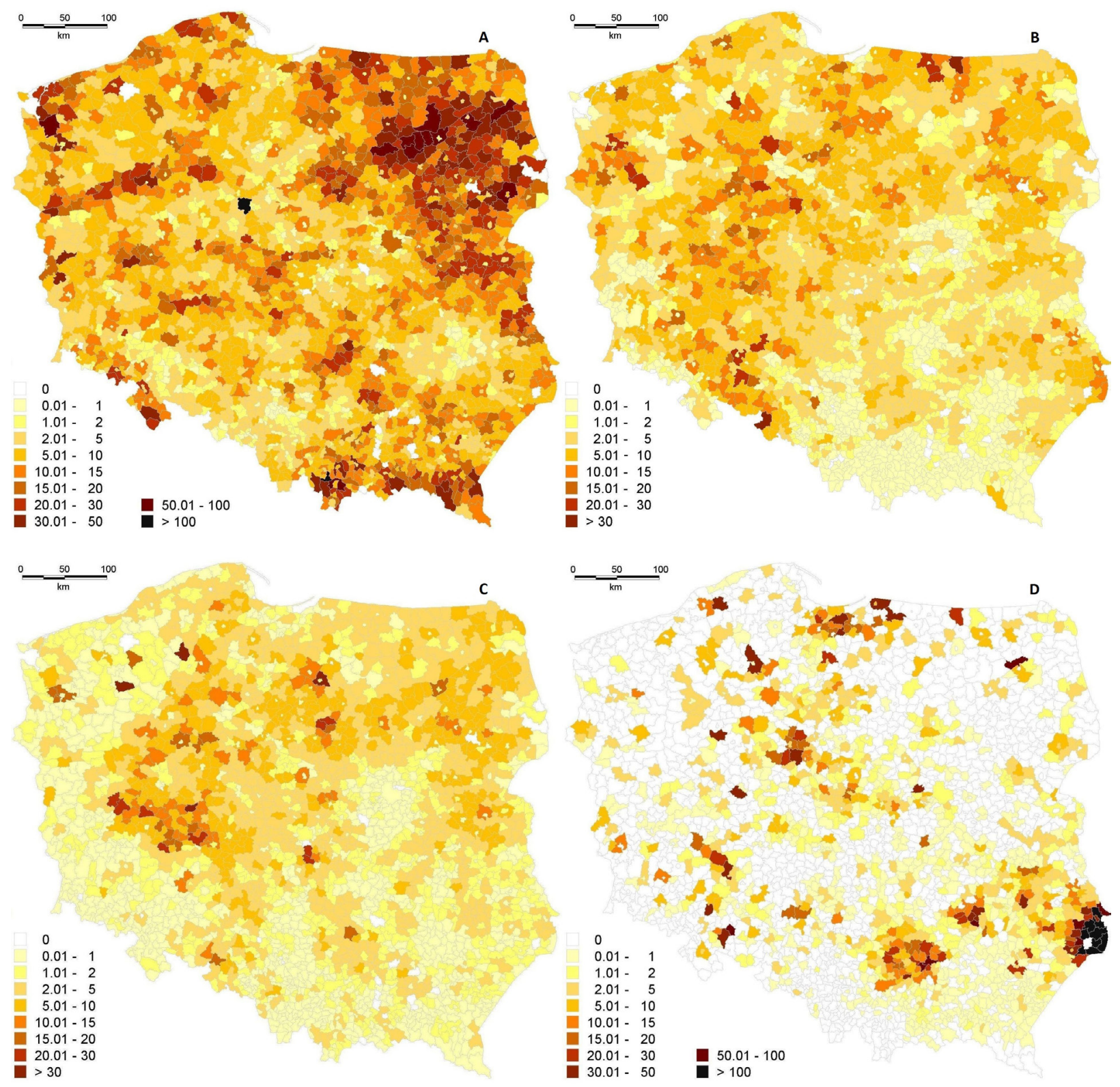

Fig. 2. Annual $\mathrm{N}_{2} \mathrm{O}$ emissions from organic soils (A), mineral fertilizers (B), natural fertilizers (C), and plant residues (D) in Polish communes $\left(\mathrm{Mg} \mathrm{N}_{2} \mathrm{O}-\mathrm{N}\right)$.

located, on which the agricultural large-area management system is still maintained, which is conducive to GHG emissions from cultivation.

The cultivation of organic soils accounts for $40.6 \%$ of the total $\mathrm{N}_{2} \mathrm{O}$ emissions associated with the use of agricultural soils. In municipalities, this share is particularly high, at $56.9 \%$, while in rural communes it is 40.3 , and $39.5 \%$ in urban-rural communes (Fig. 2A). Moreover, the use of fertilizers - both mineral (mainly in northern and western Poland, $17.8 \%$ of total emissions for agricultural soils in the Polish communes) and natural (12.9\%, mainly in the Greater Poland, Pomeranian, Kuyavian-Pomeranian and
Warmian-Mazurian Voivodeships) - is an important source of direct nitrous oxide emissions from agricultural soils (Fig. 2B, C). In rural communes, this share is the highest and reaches $17.1 \%$ for mineral fertilizers and $13.0 \%$ for natural (organic) ones. In urban-rural communes it amounts to 19.9 and $13.2 \%$, respectively, compared to 12.7 and $8.6 \%$ of total $\mathrm{N}_{2} \mathrm{O}$ emissions from agricultural soils in the municipalities. Nitrogen fertilization with crop residues accounts for $13.2 \%$ of the total $\mathrm{N}_{2} \mathrm{O}$ emissions associated with the use of agricultural soils. The highest levels of $\mathrm{N}_{2} \mathrm{O}$ emissions related to plant residues are mainly characteristic for communes located in the south-eastern and central parts 

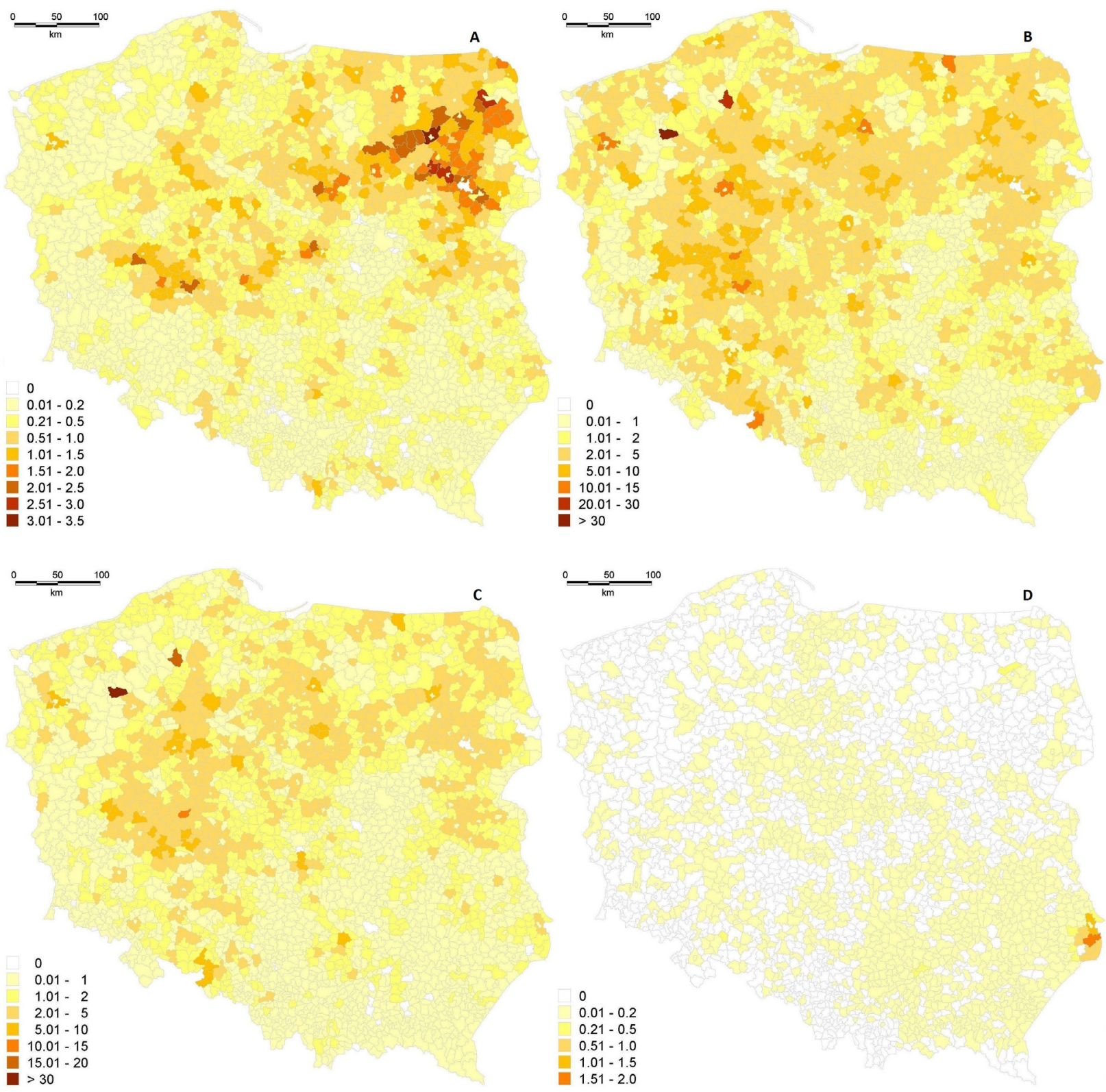

Fig. 3. Annual $\mathrm{N}_{2} \mathrm{O}$ emissions from livestock excreta (A), nitrogen leaching (B), deposition of atmospheric nitrogen (C), and edible pulses (D) in Polish communes $\left(\mathrm{Mg} \mathrm{N}_{2} \mathrm{O}-\mathrm{N}\right)$.

of the country (Fig. 2D). Furthermore, minimal importance in direct $\mathrm{N}_{2} \mathrm{O}$ emissions has been attributed to the excretion of animal faeces deposited on pastures (1.5\%). The highest $\mathrm{N}_{2} \mathrm{O}$ emissions from this source are characteristic of the communes in the central and north-eastern part of Poland, where intensive animal husbandry, including pigs and cattle, is concentrated (Fig. 3A).

Nitrogen leaching into groundwater and surface waters is the main source of indirect $\mathrm{N}_{2} \mathrm{O}$ emissions associated with the use of agricultural soils in the Polish communes (8.4\%, mainly in the western, central and north-eastern Poland). Its share of the total $\mathrm{N}_{2} \mathrm{O}$ emissions from agricul- tural soils ranges from $5.8 \%$ in the municipalities to $9.0 \%$ in urban-rural communes (Fig. 3B). The deposition of nitrogen released into the air from fields in the form of nitrogen oxide $\left(\mathrm{NO}_{\mathrm{x}}\right)$ and ammonia $\left(\mathrm{NH}_{3}\right)$, after the application of natural (organic) and inorganic fertilizers, is significantly less important than indirect $\mathrm{N}_{2} \mathrm{O}$ emissions (Fig. 3C). It corresponds to $5.8 \%$ of total $\mathrm{N}_{2} \mathrm{O}$ emissions from agricultural soils in urban-rural communes, $5.4 \%$ in rural communes, and $3.7 \%$ in municipalities.

Due to the significant share of total GHG emissions produced by agricultural soils, they should be included in the development of a low-carbon economy at the local level in 
Poland. Identifying $\mathrm{N}_{2} \mathrm{O}$ emissions from agricultural soils would aid in the reduction of these emissions and mitigate their negative effects on the atmosphere, climate and other elements of the ecosystem. This is of particular importance in rural and urban-rural communes, but should also be considered in municipalities, where a significant share of the land is agricultural land or is home to a high degree of biological activity. When formulating an action plan, it is necessary to pay particular attention to exploring the potential of agricultural and rural areas (including agricultural soils) in order to reduce GHG emissions. For example, Syp et al. (2015), when assessing the impact of management practices on gas emissions and $\mathrm{N}$ losses calculated using the DNDC model, state that the $\mathrm{N}$ losses and GHG emissions could be minimized by controlling $\mathrm{N}$ application through the implementation of a nutrient management plan in which $\mathrm{N}$ doses are defined based on the crop needs and soil quality. However, as emphasized by Bennetzen et al. (2016), agricultural GHG emissions can only be reduced to a certain level and a simultaneous focus on other parts of the food-system is necessary in order to increase food security whilst reducing emissions.

\section{CONCLUSIONS}

1. The annual $\mathrm{N}_{2} \mathrm{O}$ emissions from agricultural soils in Polish communes range from $0.002 \mathrm{Mg} \mathrm{N}_{2} \mathrm{O}-\mathrm{N}$ to 437.77 $\mathrm{Mg} \mathrm{N}_{2} \mathrm{O}-\mathrm{N}$, with an average value of $21.13 \mathrm{Mg} \mathrm{N}_{2} \mathrm{O}-\mathrm{N}$ and a standard deviation of $23.86 \mathrm{Mg} \mathrm{N}_{2} \mathrm{O}-\mathrm{N}$.

2. The highest $\mathrm{N}_{2} \mathrm{O}$ emissions related to agricultural land use are characteristic mainly for communes located in the northern and north-eastern part of the country, where the share of organic soils is dominant. The $40.6 \%$ of the total $\mathrm{N}_{2} \mathrm{O}$ emissions associated with the use of agricultural soils come from the cultivation of organic soils. The use of mineral fertilizers (17.8\% of $\mathrm{N}_{2} \mathrm{O}$ emissions) and organic fertilizers (12.9\%) is also significant. The use of high doses of nitrogen fertilizers is the main source of $\mathrm{N}_{2} \mathrm{O}$ emissions in the northern part of Poland. Whereas, in the northeast part there are farms specializing in milk production, and manure is the main source of $\mathrm{N}_{2} \mathrm{O}$ emissions. A significant share in the direct emission of nitrous oxide (mainly in the south-eastern part of the country) is also nitrogen fertilization with post-harvest residues (13.2\%). The leaching of nitrogen into groundwater and surface water $(8.4 \%)$ is the main source of indirect emissions associated with the agricultural use of soils.

3. The results confirm the need to include GHG emissions from agricultural soils and other agricultural sources in low-carbon economy plans. This need particularly applies to rural and urban-rural communes, but it requires even more consideration in municipalities, where a significant share of the land is agricultural land or is home to a high degree of biological activity.
4. The results obtained for the whole country may be used to provide a database for local governments, which will allow, not only for the identification of local emission sources related to agricultural soils, but also for adequate planning in order to prioritize measures for its reduction.

Conflict of interest: The Authors do not declare conflict of interest.

\section{REFERENCES}

Bange H.W., 2008. Gaseous Nitrogen Compounds ( $\mathrm{NO}, \mathrm{N}_{2} \mathrm{O}, \mathrm{N}_{2}$, $\mathrm{NH}_{3}$ ) in the Ocean. In: Nitrogen in the Marine Environment (Second Edition) (Eds. D.G. Capone, D.A. Bronk, M.R. Mulholland, E.J. Carpenter). Burlington, MA, USA. https:// doi.org/10.1016/b978-0-12-372522-6.00002-5

Bennetzen E.H., Smith P., and Porter, J.R., 2016. Decoupling of greenhouse gas emissions from global agricultural production: 1970-2050. Global Change Biology, 22, 763-781. https://doi.org/10.1111/gcb.13120

Bouwman A.F., 1996. Direct emission of nitrous oxide from agricultural soils. Nutrient Cycling in Agroecosystems, 46, 53-70. https://doi.org/10.1007/bf00210224

Bremner J.M., 1997. Sources of nitrous oxide in soils. Nutrient Cycling in Agroecosystems, 49, 7-16.

Broucek J., 2018. Nitrous Oxide Release from Poultry and Pig Housing. Polish J. Environ. Studies, 27(2), 467-479. https:// doi.org/10.15244/pjoes/75871

Butterbach-Bahl K., Baggs E.M., Dannenmann M., Kiese R., and Zechmeister-Boltenstern S., 2013. Nitrous oxide emissions from soils: how well do we understand the processes and their controls? Philosophical Transactions of the Royal Society B: Biological Sciences, 368(1621), 1-13. https://doi.org/10.1098/rstb.2013.0122

Czubaszek R. and Wysocka-Czubaszek A., 2018. Emissions of carbon dioxide and methane from fields fertilized with digestate from an agricultural biogas plant. Int. Agrophys., 32, 29-37. https://doi.org/10.1515/intag-2016-0087

Eurostat, 2017. Agri-environmental indicator - greenhouse gas emissions. Statistics Explained, Luxembourg, European Union.

Finlayson-Pitts B.J. and Pitts J.N., 2000. Global Tropospheric Chemistry and Climate Change. In: Chemistry of the Upper and Lower Atmosphere (Eds B.J. Finlayson-Pitts, J.N. Pitts). Academic Press, San Diego, California, USA. https://doi.org/10.1016/b978-012257060-5/50016-2

Fotyma E., Fotyma M., and Pietruch Cz., 2004. The content of mineral nitrogen Nmin in arable soils of Poland (in Polish). Fertilizers and Fertilization, 3(20), 11-54. https://doi. org/10.1007/978-94-009-1586-2_6

Hénault C., Grossel A., Mary B., Roussel M., and Leonard J., 2012. Nitrous oxide emission by agricultural soils: A review of spatial and temporal variability for mitigation. Pedosphere, 22(4), 426-433. https://doi.org/10.1016/ s1002-0160(12)60029-0

IPCC, 2000. Good practice guidance and uncertainty management in national greenhouse gas inventories. Intergovernmental Panel on Climate Change, Hayama, Kanagawa, Japan. 
IPCC, 2006. IPCC Guidelines for National Greenhouse Gas Inventories. Intergovernmental Panel on Climate Change, Hayama, Kanagawa, Japan.

IPCC, 2013. Climate Change 2013: The Physical Science Basis. Contribution of Working Group I to the Fifth Assessment Report of the Intergovernmental Panel on Climate Change. Cambridge University Press, New York, NY, USA. https:// doi.org/10.1017/cbo9781107415324.023

Jarosz Z., Faber A., and Syp A., 2013. An assessment of changes in the greenhouse gas emission following a switch from conventional to organic farming (in Polish). WaterEnvironment-Rural Areas, 4(44), 43-53.

Khalil K., Mary B., and Renault P., 2004. Nitrous oxide production by nitrification and denitrification in soil aggregates as affected by $\mathrm{O}_{2}$ concentration. Soil Biol. Biochem., 36(4), 687-699. https://doi.org/10.1016/j.soilbio.2004.01.004

KOBiZE, 2017. Poland's National Inventory Report 2017. Greenhouse Gas Inventory for 1988-2015. The National Centre for Emission Management, Warsaw, Poland.

KOBiZE, 2018. Poland's National Inventory Report 2018. Greenhouse Gas Inventory for 1988-2016. The National Centre for Emission Management, Warsaw, Poland.

Letey J. and Vaughan P., 2013. Soil type, crop and irrigation technique affect nitrogen leaching to groundwater. California Agric., 67(4), 231-241. https://doi.org/10.3733/ ca.e.v067n04p231

Mercik S., Moskal S., and Stępień W., 1995. Nitrous oxide emission from agricultural soils in Poland in connection with greenhouse gases effect (in Polish). Soil Sci. Annual, 46(1/2), 135-148.

Nyćkowiak J., Leśny J., Juszczak R., Olejnik J., Blecharczyk A., Haas E., Kiese R., and Butterbach-Bahl K., 2013. Application of landscape DNDC model for simulating soil water content and crop yield quantity (in Polish). Rocznik Ochrona Środowiska, 15, 1937-1951.

Nyćkowiak J., Leśny J., Merbold L., Niu S., Haas E., Kiese R., Butterbach-Bahl K., and Olejnik J., 2014. Direct $\mathrm{N}_{2} \mathrm{O}$ emission from agricultural soils in Poland between 1960 and 2009. Regional Environmental Change, 14, 1073-1082. https://doi.org/10.1007/s10113-013-0543-2

Nyćkowiak J., Leśny J., and Olejnik J., 2012. Evaluation of direct $\mathrm{N}_{2} \mathrm{O}$ emission from agricultural soils in Poznań Province for the period of 1960-2009, according to IPCC methodology. Water-Environment-Rural Areas, 4(40), 203-215.

Ohshiro M., Hossain Md. A., Nakamura I., Akamine H., Tamaki M., Bhowmik P.Ch., and Nose A., 2016. Effects of soil types and fertilizers on growth, yield, and quality of edible Amaranthus tricolor lines in Okinawa, Japan. Plant Production Sci., 19(1), 61-72. https://doi.org/10.1080/1343 943x.2015.1128087

Okruszko H. and Piaścik H., 1990. Characterization of the hydrogenic soils (in Polish). ART Publishing House, Olsztyn, Poland.

Portmann R.W., Daniel J.S., and Ravishankara A.R., 2012. Stratospheric ozone depletion due to nitrous oxide: influences of other gases. Philosophical Transactions of the Royal Society B: Biological Sciences, 367(1593), 12561264. https://doi.org/10.1098/rstb.2011.0377

Prather M.J., Hsu J., Deluca N.M., Jackman C.H., Oman L.D., Douglass A.R., Fleming E.L., Strahan S.E., Steenrod S.D.,
Søvde O.A., Isaksen I.S.A, Froidevaux L., and Funke B., 2015. Measuring and modeling the lifetime of nitrous oxide including its variability. J. Geophysical Res.: Atmospheres, 120(11), 5693-5705. https://doi.org/10.1002/2015jd023267

Sapek A., 2008. Emission of nitrogen oxides $\left(\mathrm{NO}_{\mathrm{x}}\right)$ from crop soils and natural ecosystems (in Polish). WaterEnvironment-Rural Areas, 1(22), 283-304.

Schlesinger W.H. and Bernhardt E.S., 2013. The global cycles of nitrogen and phosphorus. Biogeochemistry. Academic Press, Waltham, MA, USA.

Stalenga J. and Kawalec A., 2008. Emission of greenhouse gases and soil organic matter balance in different farming systems. Int. Agrophysics, 22, 287-290.

Syp A. and Faber A., 2016. Comparison of $\mathrm{N}_{2} \mathrm{O}$ emissions from winter wheat cultivation in Poland applying IPCC (Tier 1) method and DNDC model (in Polish). Annals of the Polish Association of Agriculture and Agribusiness Economists, 18(1), 254-259.

Syp A. and Faber A., 2017. Using different models to estimate $\mathrm{n}_{2} \mathrm{O}$ fluxes from maize cultivation in Poland. Polish J. Environ. Studies, 26(6), 2759-2766. https://doi. org/10.15244/pjoes/70926

Syp A., Faber A., and Kozak M., 2016. Assessment of $\mathrm{N}_{2} \mathrm{O}$ emissions from rapeseed cultivation in Poland by various approaches. Int. Agrophys., 30, 501-507. https://doi. org/10.1515/intag-2016-0013

Syp A., Faber A., and Pikula D., 2015. Assessing the impact of management practices on gas emissions and $\mathrm{N}$ losses calculated with denitrification-decomposition model. Plant, Soil and Environ., 61(10), 433-437. https://doi. org/10.17221/15/2015-pse

Turbiak J., Miatkowski Z., Chrzanowski S., Gąsiewska A., and Burczyk P., 2011. Dinitrogen oxide emission from a peat-muck soil in the Biebrza river valley in relation to water conditions (in Polish). Water-Environment-Rural Areas, 4(36), 239-245.

Wang X.G., Sistla S.A., Wang X.B., Lü X.T., and Han X.G., 2016. Carbon and nitrogen contents in particle-size fractions of topsoil along a $3000 \mathrm{~km}$ aridity gradient in grasslands of northern China. Biogeosciences, 13, 36353646. https://doi.org/10.5194/bg-13-3635-2016

Wilson T., Warren J., and Raun W.R., 2013. Nitrous Oxide Emissions From Winter Wheat. Conf. Paper ASA, CSSA, \& SSSA International Annual Meetings, November 3-6, Tampa, Florida, USA.

Wiśniewski P. and Kistowski M., 2017a. Agriculture and rural areas in the local planning of low carbon economy in light of the idea of sustainable development - results from a case study in north-central Poland. Fresenius Environmental Bulletin, 26(8), 4927-4935.

Wiśniewski P. and Kistowski M., 2017b. Low-carbon development of rural areas in Poland against low-carbon economy planning (in Polish). UG Publishing House, Gdańsk, Poland.

Wiśniewski P. and Kistowski M., 2017c. The use of agricultural soils as a source of nitrous oxide emission in selected communes of Poland. Bulletin of Geography. Physical Geography Series, 13, 39-49. https://doi.org/10.1515/ bgeo-2017-0012

Wiśniewski P. and Kistowski M., 2018. Assessment of greenhouse gas emissions from agricultural sources in order to 
plan for needs of low carbon economy at local level in Poland. Geografisk Tidsskrift-Danish J. Geography, 118(2), 123-136. https://doi.org/10.1080/00167223.2018.1436447

Włodarczyk T., Stępniewski W., Brzezińska M., and Kotowska U., 2002. $\mathrm{N}_{2} \mathrm{O}$ emission and sorption in relation to soil dehydrogenase activity and redox potential. Int. Agrophysics, $16,249-252$.
Wójcik-Gront E., 2015. Territorial analysis of agricultural greenhouse gas emission in Poland. Applied Ecology Environ. Res., 13(2), 417-425.

Wójcik-Gront E. and Gront D., 2014. Assessing Uncertainty in the Polish Agricultural Greenhouse Gas Emission Inventory Using Monte Carlo Simulation. Outlook on Agriculture, 43(1), 61-65. https://doi.org/10.5367/oa.2014.0155 